\title{
Editorial
}

\section{Whose Colonialism? Which Empire?}

\author{
Bruce Kaye
}

All social groups contain differences. Those that exist over time have to sustain themselves through the conflicts that difference and belonging create. There has always been conflict in Christianity and its sub-traditions. Anglicanism is no exception. In the continuing story of Anglicanism practices have developed to sustain faith and contain conflict. In the last 50 years Anglicans have been experimenting with global institutions in response to shrinking distances between provinces. Efforts to see how the story relates to these experiments have uncovered in the Communion some of the dynamics of power, its character and the manner of its exercise. We benefit from confronting these usually unstated dynamics.

In his 1988 book Whose Justice? Which Rationality? Alasdair MacIntyre argued that concepts of justice only made sense within the framework of a rationality, which was sustained in a continuing community. One of the enduring issues from his book was that the practices and beliefs of a community embodied a way of thinking which made those practices and beliefs intelligible.

One might have thought that such an idea could be usefully applied to a religious tradition like Anglicanism but we would need to be a little cautious in doing so too quickly. Certainly a case can be made for seeing Anglicanism in its historical formation as a tradition community with an identifiable range of practices and beliefs. Indeed that is probably the best way to see it. However, the very nature of Anglicanism invites into the dynamic of its own life influences from the different contexts in which Anglicans live out their faith. The impulse to live faithfully where you are is embedded deep in the Anglican history and faith and that means engaging with that context. Anglicans shape their community life and institutions in the light of that engagement. This is the arena of experimentation and reform in the continuing process of seeking to be faithful to the gospel in the life of the community, of being in the world but not of it.

It is therefore worth reflecting on the context in which the contemporary form of the Anglican Communion has come into being. 
In doing so we should make a distinction between the origins and formation of Anglicanism as a religious tradition within western Christianity on the one hand and the development of a global sense to the tradition. The emergence of a discrete tradition of Christianity that can reasonably be said to be the beginnings of Anglicanism occurs in the eighth century with the creative work of the Venerable Bede. ${ }^{1}$ The emergence of an international community of Anglican churches should probably be dated from the agreement between Seabury and the Scottish Episcopal bishops who consecrated him. ${ }^{2}$ The emergence of a sense of a global community of Anglican churches came a long time later. That it came late and that Anglicans have continued to find it to be a difficult process should not be surprising since this religious tradition has run a thousand-year argument with Roman Catholicism over the nature of universality and of catholicity in the church.

What is not so often noticed is that the present institutions of the Anglican Communion were shaped mainly after the Second World War in the twentieth century. The Lambeth Conference had existed as a determinedly consultative meeting since 1867 and the Archbishop of Canterbury had retained a position of respect from the English period. But the modification of the Lambeth Conference into something thought to be more than just a consultation of bishops and the role of the Archbishop of Canterbury into a more presiding role in the Communion only occurred in the post World War II period.

These changes took place in a volatile imperial/colonial environment. During the period the US came to pre-eminence as a world power and a 'virtual' empire conducting a 'Cold War' with that other empire, the USSR and its colonies, or client states. The term 'Third World' was formulated to describe that part of the globe not covered by the two competing empires of this Cold War when much of Africa, South America and Asia was an arena of Cold War competition. The terms of that competition were often economic and cultural. At the time when the USA was prosecuting this cold war competition and consolidating its informal empire Britain was giving up its empire. After touring British colonies in Africa during January 1960, the British Prime Minister Harold Macmillan in a speech to the South African Parliament on 3 February declared that a wind of change was blowing through Africa, and that whether we liked it or not, the growth of

1. See B. Kaye, An Introduction to World Anglicanism (Cambridge: Cambridge University Press, 2008), pp. 7-54.

2. For the details of this agreement see P.H.E. Thomas, 'Unity and Concord: An Early Anglican "Communion"', Journal of Anglican Studies 2.1 (2004), pp. 9-21. 
national consciousness was a political fact. Thus was announced the rapid de-colonization of the British Empire. That process was mirrored by the Geoffrey Fisher project of encouraging Anglican churches in newly independent nations to become independent churches with their own constitutions set in their own national circumstances.

Not all empires have the same profile of authority or control in relation to their colonies as can be seen in the different stages of the British Empire. The issue at stake in empire and colonialism is the autonomy and competence of the nation or its relations of dependence upon others. It is about power. What kind of power and how it is exercised. Contemporary post-colonialism literature focuses on the implications of colonial relations past and present. The issue embedded here is the character of former colonies that have become independent nations as much as the former imperial nation. What applies to such nations applies as well to all Anglican provinces. What kind of power and how is it exercised in that province.

These are complex matters that have had a significant influence on the emergence of the modern Anglican Communion and its structured relationships. In the period following World War II the pan Anglican congresses flowed on impulses from North America in the direction of more substantial global institutions in a way that was not true of the earlier 1908 congress. In this period vast sum of money moved from Episcopalians in the USA to other parts of the Anglican Communion in unbridled generosity. The funding of the Episcopal Church of America and the influence of its national culture were very clear in this period and have left their mark on the shape of the Anglican Communion at the end of the twentieth century.

These broader dynamics are inevitably at play in current relations between churches in the Anglican Communion. They also influence the way we conceptualise the character of the Anglican Communion. Is the Anglican Communion the essential entity of which the member churches are constituent parts as one recent English report suggests? Or was an earlier report to a Lambeth Conference that such a topdown conception was not only non-Anglican but also not satisfactorily Christian? What kind of power exists in those recent and novel institutional experiments that are currently described as 'Instruments of Unity', and how can or should it be exercised? Should the Anglican Communion be viewed from the centre or the periphery, and in any case whose centre and whose periphery?

Such issues around post-colonial and imperial impulses are canvassed in this issue of the JAS. We publish here some of the papers from a conference held in Manchester, England in 2008. I express my 
gratitude to Joseph Duggan for his work in relation to that conference and in the preparation of the papers published here. We have also in this issue an article from Andrew Village and others, which also draws attention to the social background of allegiances to different points of view within English Anglicanism.

These articles raise fundamental questions about the way in which Anglicans properly reflect elements of what Charles Taylor calls the 'immanent frame' of our situation and in what way they should properly dissent from those attitudes and assumptions. How we are to be in the world but not of the world applies to our overt actions and also shapes how we engage with the values and assumptions tacit in our own particular situations. That is one of the more important, but often unexamined, forces at work in the present condition of worldwide Anglicanism, which this issue brings out into the open more clearly. 